\title{
1. Introduction to the Research Handbook on the Politics of EU Law
}

\author{
Marie-Pierre Granger and Paul James Cardwell
}

Is there ever an ideal time to publish a volume on the contemporary state of law and politics in the European Union (EU)? The entry into force of the Treaty of Lisbon (2009), having 'rescued' parts of the Draft Treaty Establishing a Constitution for Europe, was supposed to herald a new chapter in European integration, with greater institutional stability and coherence, a consolidation of its achievements and a focus on furthering integration in areas where only limited steps had been taken.

However, despite the advanced stage of European integration, the decade since Lisbon has been marked by a series of crises. Whilst the EU is certainly used to facing serious crises, dealing with them and often emerging with renewed goals and impetus, many of the recent challenges are unprecedented and go to the heart of what the EU is - and stands for. The economic and financial crises; questions over the future of the euro; the lack of collective responses to migration and regional instability; democratic and rule of law backsliding in some Member States; the UK referendum on leaving the EU and the complexities of Brexit negotiations, and more recently the challenges of coordinating the fight against the coronavirus pandemia, have dominated the debates. All bring to the fore the complex relationship between law and politics in the EU, and revive or renew discussions about the role of law and legal actors in European integration.

Law has always played a central role in European integration. ${ }^{1}$ Whilst new forms of integration take shape, and modes of governance have diversified, law continues to play a primordial, yet evolving, role in EU integration and governance in general, and in addressing these multiple challenges. EU law, in any case, does not operate in a political and social vacuum. It is influenced by multiple societal forces and impacts back on them in a continually iterative process.

This Research Handbook introduces and considers contemporary academic perspectives on the politics of EU law. Its object of study is the law of the EU, in its various forms and shapes, its complex and multifaceted institutional framework and system of governance, the broad spectrum of policies it covers, and its relationship with emerging forms of global law. The ongoing challenges facing the EU have thrown a different light on European integration and governance, and invited (or even forced) scholars to revisit some assumptions about the dynamics, nature and purpose

1 M Cappelletti, M Seccombe and JHH Weiler (eds), Integration Through Law: Europe and the American Federal Experience, Vol 1 Methods, Tools and Institutions (Walter de Gruyter and Co 1986). 
of European integration, and the role law plays - and ought to play - in it. The current academic focus on crises, however, carries with it the risk of losing sight of the richness of the EU's political and legal horizons, and of the vibrancy of scholarly interest in the EU, which shows no sign of waning. Whilst many of the contributions in the Handbook expose and assess the role of law in dealing with the EU's crises, the project also cares to step back, and reflect more broadly on the changing role of law in European integration and governance, and what factors, actors and processes influence its evolution and its impact on politics and society in Europe and beyond.

The Handbook continues and contributes to a solid tradition in EU legal studies of looking beyond doctrinal or black-letter accounts of law, to its political and social underpinnings and implications in the process of building Europe. ${ }^{2}$ The early decades of EU law as an academic field were characterised by doctrinal scholarship promoting what was then the law of the Communities, and praising its interpretation and implementation by the 'heroic' Court of Justice of the EU (CJEU). However, accounts started to change in the late 1980s, with more works that paid closer attention to the social and political context of legal integration. ${ }^{3}$ Legal scholars adopted a more critical stance to their object of study, engaging with, and influenced by, the theories and methods of other disciplines, in particular those of international relations, political sciences and economics, and more recently sociology and history. The now rich and diverse 'law-in-context' scholarship on the EU, which this Handbook seeks to broadcast, is usually traced back to the 'integration-through-law' series. ${ }^{4}$ It has, over the years, not only infiltrated traditional legal publication venues, but also opened up new academic outlets. ${ }^{5}$

Whilst looking for explanations which emphasise non-legal factors, such as power politics (for example, Member State governments' influence in EU affairs), economic pressures (corporate lobbying of EU regulators, or firms' litigation strategies) or societal pressure (such as NGO activism or the impact of public opinion), law-in-context approaches are not particularly interested in developing parsimonious explanations teasing out the explanatory leverage of selected 'variables'. They tend to readily embrace the complexity of legal phenomena, and their relationship to the

2 See, for instance, A Grimmel, 'The Uniting of Europe by Transclusion: Understanding the Contextual Conditions of Integration Through Law' (2014) 36(6) Journal of European Integration 549.

3 For a critical overview of this evolution, see J Hunt and J Shaw, 'Fairy Tale of Luxembourg? Reflections on Law and Legal Scholarship in European Integration', in D Phinnemore and A Warleigh-Lack (eds), Reflections on European Integration (Palgrave Macmillan 2009).

4 For early seminal contributions, see E Stein, 'Lawyers, Judges, and the Making of a Transnational Constitution' (1981) 75(1) American Journal of International Law 1; JHH Weiler, 'The Transformation of Europe' (1991) Yale Law Journal 2403. For a more recent reflection on the troubled relations between law and integration in Europe, see L Azoulai, “"Integration Through Law" and Us' (2016) 14(2) International Journal of Constitutional Law 449 .

Such as the European Law Journal. 
political and social, with the risk of, sometimes, losing sight of what actually, and eventually, matters.

Critical legal scholarship, for its part, finds inspiration in political theories and the American critical legal studies tradition to scrutinise the role(s) law has played in the EU project, its emancipatory or alienating nature, and to revisit normative implications. ${ }^{6}$

Alongside and intermingling with legal academics, scholars from other disciplines have long displayed a keen interest in integration through law. Picking up in the early 1990s, political scientists started looking more closely into the dynamics of the constitutionalisation of EU law and its impact on political integration. Neo-functionalists, in particular, found in legal integration an ideal terrain to deploy the analytical leverage of their favoured theoretical perspective, with spill-overs from one legal area to the next and from law into politics, through a process driven by self-interested supranational institutions (integrationist and power-seeking Court and Commission) and sub-national actors (including market actors, legal elites and national courts). ${ }^{7}$ Integration by judicial fiat, together with the structuring role of precedent, offered new institutionalists taking a historical stance a good testing ground for path-dependent explanations and the logics of unintended consequences. ${ }^{8}$ Those in the rational choice tradition provided means of assessing the scope and limits of principal-agent explanations, and developed arguments on the autonomy of supranational institutions, such as the CJEU, in driving European integration. ${ }^{9}$ Comparative political perspectives studied the special role law and legal processes played in the EU 'judicialised' governance context. ${ }^{10}$ More recently, new intergovernmentalism, taking stock of changing modes of integration since Maastricht and

\footnotetext{
6 See the chapters in this volume by Everson and Fahey.

7 See AM Burley and W Mattli, 'Europe Before the Court: A Political Theory of Legal Integration' (1993) 47(1) International Organization 41; W Mattli and AM Slaughter, 'Law and Politics in the European Union: A Reply to Garrett' (1998) 49(1) International Organization 183; A Stone Sweet and W Sandholtz, 'European Integration and Supranational Governance' (1997) 4(3) Journal of European Public Policy 297; A Stone Sweet and T Brunell, 'Constructing a Supranational Constitution: Dispute Resolution and Governance in the European Community' (1998) 92 American Political Science Review 63; KJ Alter, Establishing the Supremacy of European Law: The Making of an International Rule of Law in Europe (Oxford University Press 2001); KJ Alter, The European Court's Political Power: Selected Essays (Oxford University Press 2010).

8 See, for instance, A Stone Sweet and TL Brunell, The Judicial Construction of Europe (Oxford University Press 2004); for a more recent take on the matter, SK Schmidt, "Who Cares About Nationality? The Path-dependent Case Law of the ECJ from Goods to Citizens' (2000) 19(1) Journal of European Public Policy 8.

9 MA Pollack, The Engines of European Integration: Delegation, Agency, and Agenda-Setting in the EU (Oxford University Press 2003); J Tallberg, 'The Anatomy of Autonomy: An Institutional Account of Variation in Supranational Influence' (2000) 38(5) JCMS: Journal of Common Market Studies 843.

10 RD Kelemen, Eurolegalism: The Transformation of Law and Regulation in the European Union (Harvard University Press 2011).
} 
their dealings with recent crises, outlines the changing role of law in the new institutional context and political and social dynamics which characterise the EU today; it reflects on the apparent demise of the Community method and technical/functional modes of integration, and the central role law had traditionally played in it, and on the implications of the increasing politicisation of EU policy-making. ${ }^{11}$

Europeanisation scholars have, for their part, investigated more systematically the factors (including domestic politics) that affect the implementation and application of EU law. Some of the contributions in this Handbook belong to this now rich political science literature exploring the interactions between politics and law in the EU.

These political science works help us develop a more systematic understanding of the broader institutional dynamics which shape the development and implementation of EU law, and the varying roles and influence of different sets of actors (governments, courts, supranational institutions, litigants, lobbies and so on) in and across various law-making and implementation settings, and policy areas. ${ }^{12}$ They had led to fruitful interdisciplinary collaborations, which offer more comprehensive but also more nuanced perspectives on integration through law. ${ }^{13}$

Over more recent years, sociological and historical studies, digging deeper into the societal roots of EU law, started to reveal a different picture of its development and influence. They expose in plain sight the important role played by lawyers in both judicial and political circles of power in Europe. ${ }^{14}$ For instance, we now know that the 'descriptive' or 'normative-prescriptive' studies of institutional and substantive EU law, and the powerful story of its constitutionalisation, which dominated legal publications until the 1990s, were, to a large extent, produced by the same legal minds that were at the same time making EU law. In other words, academic commentaries on EU law were an integral part of the political and societal project of building Europe through law. We also start to understand better how particular actors, such as NGOs and corporate actors, push for legal change at EU level and mobilise EU law to

11 PJ Cardwell and TK Hervey, 'The Roles of Law in a New Intergovernmentalist European Union', in C Bickerton, D Hodson and U Puetter (eds), The New Intergovernmentalism: States and Supranational Actors in the Post-Maastricht Era (Oxford University Press 2015).

12 For reviews, see L Conant, 'The Politics of Legal Integration' (2007) 45(1) JCMS: Journal of Common Market Studies 45; A Stone Sweet, 'The European Court of Justice and the Judicialization of EU Governance' (2010) 5(2) Living Reviews in European Governance 1; RD Kelemen and SK Schmidt, 'Introduction - the European Court of Justice and Legal Integration: Perpetual Momentum?' (2012) 19(1) Journal of European Public Policy 1.

13 See, for instance, the chapter in this volume by Terpan and Saurugger. See also their book, S Saurugger and F Terpan, The Court of Justice of the European Union and the Politics of Law (Palgrave Macmillan 2016).

14 See A Jettinghoff and H Schepel (eds), In Lawyers' Circles: Lawyers and European Legal Integration (Elsevier 2004); A Vauchez, 'The Force of a Weak Field: Law and Lawyers in the Government of the European Union (For a Renewed Research Agenda)' (2008) 2(2) International Political Sociology 128; A Vauchez, Brokering Europe. Euro-Lawyers and the Making of a Transnational Polity (Cambridge University Press 2015). 
achieve policy reform. ${ }^{15}$ Although not explicitly endorsing sociological perspectives, many of the chapters in this volume explore the part played by specific actors in promoting the development of EU law or resisting its influence, and the processes at play. ${ }^{16}$ This Handbook underlines the continued importance of understanding the law of the EU through the perspective of writers from outside legal scholarship as traditionally understood.

The Handbook addresses cross-cutting issues relating to the institutional order and system of governance, and some of the substantive areas where law and politics meet. Given the breadth of the EU's activities, it was not possible to include them all. Instead, the chapters cover a selection of identifiable legal-policy areas as well as issues which feed into different dimensions of the EU integration process across a number of fields. Some are long-standing areas of interest in EU studies whilst others represent more recently emerging fields. To allow for consistency across such a wide and diverse set of scholarly interests, contributors to the Handbook were asked to consider the following questions: Where are the main sites of interaction between law and politics in the area under examination? What theoretical insights help us best understand the area? How can we understand the direction of travel in that area and potential research agenda(s) for the future? The chapters do not treat all these questions systematically but permit an understanding of how the politics of EU law unfold in each of the areas or issues under examination and engage with the contemporary state of the art.

To facilitate the exploration of the rich horizon of contemporary scholarship on the EU, this Handbook is divided in two parts. The first looks at the institutional level of analysis, considering the theory and practice of how the EU institutions evolve, including in their interactions with other actors. The second examines in more detail some of the substantive areas where the politics of EU law can be traced and explained. This part is not exhaustive in terms of the areas of competence or policy that the EU is involved in, but gives an overview of how the politics and the law have interacted in different ways over the course of the history of European integration and in the contemporary context.

The first part of the Handbook examines the key questions noted above insofar as they concern the institutions of the EU, how the institutions relate to each other and interact, and how they are composed. Institutional questions are quintessential in understanding where the politics of law-making occur, which can also arise in national contexts, but which have always had a special resonance in the EU's sui generis set-up. Institutional tensions feature strongly in chapters which focus on the relationships between the EU actors, but also where the institutional structures potentially include outsiders. In this vein, the first part opens with Cardwell's exploration of how to reframe the language of 'governance' to adapt to the 'post-crisis'

15 L Conant, A Hofmann, D Soennecken and L Vanhala, 'Mobilizing European Law' (2018) 25(9) Journal of European Public Policy 1376.

16 See the chapters in this volume by Granger, and Heindlmaier and Blauberger. 
era, especially in using governance in a way which does not necessarily incorporate the positive connotations of its language. Terpan and Saurugger demonstrate that even when discussing the Court of Justice - which as a court would be the predominant home for legal accounts of the EU - there is an extensive role to play for political-based accounts of the EU's governance structure(s). Sánchez-Barrueco also focuses on the CJEU, but - in a way which is consistent with the approach taken in the previous chapter - looks at how the Court plays the role of arbiter in conflicts between other institutions, namely the European Parliament and the Council. The differentiated subject matter at the origin of the conflicts is also revealing, and since this mode of resolving conflicts remains a contemporary feature of EU governance, the chapter suggests that understanding this dimension of interaction is key for lawyers and political scientists alike.

More recent research agendas are only possible as a result of drawing on long-term experiences. The emergence of the European Semester is analysed by Bekker, who highlights the new coordination mechanisms and socio-economic coordination cycles against the background of existing governance structures. As a newly emerging and innovative tool, she draws on some of the research familiar from other chapters in the Handbook in relation to new (modes of) governance and suggests how we might approach the study of it both theoretically and methodologically. Another recent innovation is the European Citizens' Initiative (ECI), which is analysed by Mendez and Mendez as an instance of direct democracy. Their analysis first tracks the increasing practice of national referendums on European integration, of which the Brexit vote is only one example of this phenomenon. The ECI has established itself as a visible means by which the democratic credentials of the EU's institutional framework can be tested. However, as with the European Semester, analysis of the current literature can only so far hint at what the long-term impact of this innovation will be. The Brexit theme is examined closely by Pérez-Solórzano Borragán and Smismans, as their chapter shows how studying the hitherto untested Article 50 drawing on existing scholarship of path dependency - helps illuminate institutional strategies and provide opportunities for, and constraints on, actors.

Gender equality and discrimination are well-trodden areas of EU competence and are treated extensively in the second part of the Handbook. However, in the first part, the contribution by Aldrich and Daniel considers their institutional dimension. Empirical work on national election law and party organisation processes and policies allows them to present their findings on how, with the backstop of a legal framework, gendered representation has been furthered, at least in some instances, at the EU, national and party levels. Finally, this part of the Handbook concludes with Everson's critical and future-facing contribution. She revisits the technocratic nature of EU decision-making and the distrust it has engendered. As with the previous chapters on direct democracy, this chapter tackles the EU's democratic arrangements and the 'populist assault', which downplays the role of expertise due to a reticence to use such expertise and make hard political choices. Everson suggests that expert decision-making will find its proper place within the constitutional system only where there is a recommitment to politicisation. 
The second part of the Handbook examines in more detail some of the substantive areas of activity of EU law and policy. Many of the areas under examination reflect some of the most dynamic sites of EU activity over the past decade, including citizenship and anti-discrimination. On free movement law, Heindlmaier and Blauberger show how the Court of Justice has shaped political decision-making at the European and national levels and how, in turn, these political decisions often sought to limit the Court's broader impact. The area of anti-discrimination shows how law and policy-making debates on the EU - and the accompanying research have evolved. Frese considers the long-standing scholarly and policy focus on gender equality, showing how anti-discrimination law, which was initially only constituted by a principle of equal pay, has developed into a core principle and comprehensive body of directly effective rules in the hands of the Court of Justice. Tryfonidou looks at the emerging, but highly contested, field of discrimination and sexual minorities. She explores the EU's ambivalent approach to this issue, which reflects the pressures exerted by the Member States in a contested terrain of competing visions of 'Europeanness' and human rights, on the one hand, and national identity, morality and tradition, on the other.

Social Europe figures strongly in debates about the future of the EU, and how and why this dimension of European integration can or should return to the fore. Alexandris Polomarkakis navigates the reader through the political difficulties in strengthening the social 'pillar', based on an analysis identifying the factors instrumental to Social Europe's uneven trajectory. This approach is reflected in Granger's examination of contemporary human rights law in the EU and the need to go beneath the surface to understand whether, and to what extent, it is influenced by domestic laws and practices, and in turn, impacts back on them. The remainder of the section visits sites of activity where national law and politics in the Member States have a strong effect on the politics of EU law. Labour law (Zahn), the mutual recognition of companies (Borg-Barthet) and the area of Freedom, Security and Justice (Herlin-Karnell) are areas where tensions between national and EU law have a strong effect on the extent to which integration, or cooperation, is possible. Although all three areas are subject to extensive legal-doctrinal analysis, the importance of the political dimensions to both are brought out in these contributions. In doing so, they serve as a litmus test for how the future of European integration might develop, and how we should study it. As Zahn explains, insights from the EU studies literature on Europeanisation could help legal scholars better understand the impact of 'European Labour Law' on national labour law systems. Borg-Barthet uses corporate mobility as an illustrative example of mutual recognition, as it operates in politically contentious aspects of internal market regulation. Herlin-Karnell links the technicalities of cooperation in one of the 'newer' areas with general tendencies on EU integration by looking at the flexibility mechanisms in the European Area of Freedom, Security and Justice. She highlights how the boundaries of integration and disintegration have a clear political dimension when applied to this area. The Common Agricultural Policy (CAP), despite its political salience and importance for the EU (especially in budgetary terms) has often been neglected in academic scholarship. The contribution 
by Bareli et al. draws on empirical work digging below the surface of policy-making to examine the practical (adverse) effects of the CAP on rural communities in a case study of Ikaria, Greece. The final chapters in this part examine some of the externally focused aspects of EU law and politics. Dickson's exposé of the EU's approach to migration is an appropriate contemporary example of how law-making and political bargaining in one of the EU's 'headline' areas of activity coincide. The categories of 'sought-after' migration, refugee and asylum migration, and irregular migration are used to explain the EU regulatory framework and policy priorities. Motivating rationales and limiting factors across the different EU institutions and national contexts are considered. Finally, Fahey considers the future of an interdisciplinary research agenda of EU International Relations in which court-centric arguments are combined with political bargaining to help better understand the contemporary nature of the EU. She makes the case that EU International Relations appears increasingly as a highly deserving focus of the deeper and better study of EU integration. 